\title{
Issues of Representation in Japanese Junior High School English Textbooks
}

\section{Luke Houghton \\ British Hills}

\section{Reference Data:}

Houghton, L. (2020). Issues of representation in Japanese junior high school English textbooks. In P. Clements, A. Krause, \& R. Gentry (Eds.), Teacher efficacy, learner agency. Tokyo: JALT. https://doi.org/10.37546/JALTPCP2019-06

This study is an analysis of how English and "English speakers" were represented in Japanese junior high school textbooks. The frequency of nationalities shown as English-speakers and the frequency of nations and national landmarks mentioned in the textbooks were counted with reference to Kachru's (1985) "circles" of English to identify areas of overrepresentation or underrepresentation. The ways in which English speakers were given voice were also investigated. The study found that, although the textbook authors attempted to represent the English language as spoken by a variety of nationalities, there was a bias towards representing Japanese students and inner circle nationals as the primary users of English, a severe lack of representation of people of outer circle nationalities as English speakers, and little discussion of varieties of English. 本研究では、中学生対象の検定教科書において、英語および英語話者が゙゙のよに青現されているかを調查した。英語話

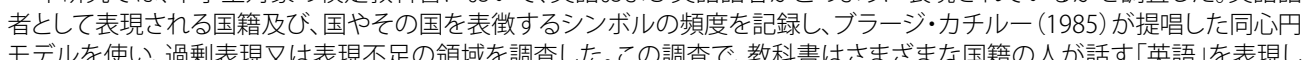
モデルを使い、過䣋表現又は表現不足の領域を調查した。この調查く、教科羓はさまざまな国籍の人が話す「英語」を表現し 外円(英語/第二言語)の国々に属する英語話者に関する表現や、様々な英語に関する議論が大幅に不足していることが分か ১た。

The commercially produced textbook is a dominant voice in the Japanese classroom.

The purpose of this study was to analyse a textbook course used in Japanese junior high schools to study how "English speakers" are represented. Although the conviction that language teaching should further intercultural understanding is discernible both in the writings on the subject (e.g., Kubota, 1998; Phillipson, 1992; Toh, 2012) and in the sales materials of textbook makers, it has been argued that representations in Japanese EFL textbooks reinforce the idea of the Anglo speaker of English as more developed or superior than others (e.g., Kubota, 1998).

\section{World Englishes}

In this study, texts were analysed through Kachru's (1985) circles of World Englishes: inner circle (IC) nations colonized through the movement of English speakers from the U.K. for permanent settlement; outer circle (OC) nations colonized by English-speaking nations (almost exclusively the U.K.) for an extended period, with institutionalized varieties of English; and expanding circle (EC) nations where English is taught in a foreign language (EFL) context.

\section{Previous Studies}

There have been many studies of English language textbooks in Japan, and evidence of a bias towards IC nations has been found from elementary textbooks (e.g., Davidson \& Liu, 2018) to a university textbook in an evaluation that found "textbooks typically construct Westerners (particularly North Americans) as the typical 'other' in relation to which Japanese cultural behaviours and values can be elucidated and contrasted" (McConachy, 2018, p. 80).

For junior high school texts, both Matsuda (2002) and Yamada (2010) are notable. Yamada (2010) analysed representations of Japan's domestic diversity and English speakers in editions of New Horizon junior high school textbooks from the 1980s to the 2000s (see Table 1). 
Table 1. Occurrences of Individuals Living in Japan in New Horizon Textbooks, by Nationality (Yamada, 2010)

\begin{tabular}{lccc}
\hline & \multicolumn{3}{c}{ Editions } \\
\cline { 2 - 4 } Nationality & $1980 \mathrm{~s}$ & $1990 \mathrm{~s}$ & $2000 \mathrm{~s}$ \\
\hline Japanese & 62 & 78 & 65 \\
Ainu & 55 & 1 & 28 \\
American & 9 & 45 & 26 \\
Australian & & 8 & \\
Brazilian & & 7 & \\
British & & 2 & 9 \\
Canadian & & 4 & \\
Singapore & & 1 & 2 \\
German & & 4 & 130 \\
Unidentified & 126 & & \\
Totals & & 66 & \\
\hline
\end{tabular}

Yamada (2010) found that IC and EC (especially Asian EC) nations were represented far more often than OC nations, and that the diversity of representations of nationalities living in Japan was at its height in the 1990s, with only IC or Japanese nationalities represented in the 2000s. Most interactions involved Japanese and IC nationals, including descriptions of marriages between Japanese and IC citizens, but not between Japanese and non-IC nationals. Mentions of IC and EC nations expressed a broader world view but one that excluded OC nations.

Similarly, Matsuda's (2002) analysis of representations of English speakers in 1styear junior high EFL textbooks found that Japanese and IC nationals produced over $88 \%$ of all spoken language, with IC nationals slightly out-producing Japanese $(46.2 \%$ to $42.7 \%$ ), despite Japanese nationals featuring more often (45.9\% of occurrences to $40.5 \%)$. Ookawa's (2017) study of high school textbooks also found that OC nations were represented far less than $\mathrm{IC}$ or EC, and that domestic Japanese issues featured heavily.

\section{The Textbooks}

In this study, I reviewed the 2016 editions of New Horizon, new editions of the course analysed by Yamada (2010), chosen due to its widespread usage. There are three books: one for each grade at junior high school. Sales reports by the national textbook distributor show this course is currently used by $29 \%$ of Japanese public junior high schools (Nippon Kyouzai Shuppan, 2019).

\section{Method}

This study quantified the frequency of mentions of three categories: nations, national landmarks, and number of words spoken by nationality. An expansion on previous studies is the counting of national landmarks, often discussed or used as settings in EFL textbooks. The following types of landmarks were included:

- geographic features (e.g., the Grand Canyon),

- man-made landmarks (e.g., the Great Wall of China), and

- cities and towns (e.g., London).

The Statue of Liberty, for example, was counted as an American landmark as New York is stated as its location; Shinto shrines were counted as Japanese as they occur in no other nation. Settings that cross national boundaries, for instance, when the Amazon was discussed, were not counted if the text did not state a specific nation.

\section{Data Collection}

As in Yamada (2010) and Ookawa (2017), nations mentioned were recorded as well as the frequency of mentions. Previous studies have not counted landmarks, so counts were repeated for landmarks. Finally, the number of words "spoken" by characters whose nationality was explicitly stated was counted. Any characters whose nationalities were unstated were not counted.

Finally, as in Matsuda (2002), spoken words were counted. Spoken words in these textbooks are instances when (a) two or more characters are shown in conversation, (b) characters are speaking in a presentation format to their class, or (c) characters are writing a letter. An appearance is classified as one character's participation in a single unit of conversation or information transfer. There are instances, however, in which an example conversation is continued in some way later in the chapter. These are counted twice, because these conversations are treated as isolated units in terms of target language, activities, and layout. 
Both Japanese and English mentions were counted, as this is a study of representations in the entirety of the textbooks, not only in the English segments of texts, though instances of immediate translation were counted only once. For example, "the UK ha igirisu no koto" [The U.K. is Igirisu in Japanese] (Kasajima \& Seki, 2016e, p. 18) was only counted as a single mention of the U.K.

\section{Results}

\section{Nations}

Tables 2 and 3 reaffirm observations from previous studies. Although of IC nations only the U.S.A., the U.K., Canada, and Australia are named, these nations were referenced 146 times: $10 \%$ of the nations mentioned took up 37\% of discussion. Conversely, 5 OC countries were mentioned (South Africa, Ghana, Kenya, Pakistan, and India), they received only 27 mentions (7\%) throughout the course.

EC nations were featured most. However, more than half of EC mentions were mentions of Japan specifically (highlighted in the right-hand column of Table 3). Japan was by far the most referenced single nation, with 110 mentions (28\%). By comparison the next most mentioned EC nation, Brazil, had 29 mentions.

Table 2. Number of Nations Mentioned in the Textbooks

\begin{tabular}{lcccc}
\hline Measure & Inner circle & Outer circle & Expanding circle & Regions \\
\hline Number of nations named & 4 & 4 & 23 & 9 \\
Percentage of total & 10 & 10 & 57.5 & 22.5 \\
\hline
\end{tabular}

Table 3. Frequency of Mentioned Nations

\begin{tabular}{lccccc}
\hline Measure & Inner circle & Outer circle & Expanding circle & Regions & Japan \\
\hline $\begin{array}{l}\text { Number of nations } \\
\text { named }\end{array}$ & 146 & 27 & 207 & 18 & 110 \\
Percentage of total & 36.7 & 6.8 & 52.0 & 4.5 & 27.6 \\
\hline
\end{tabular}

\section{National Landmarks}

The same four IC nations were mentioned most often - the U.S.A, the U.K., Canada, and Australia. These nations were only $27 \%$ of all nations whose landmarks were mentioned, yet they were $53 \%$ of all mentions. OC landmarks barely appeared: three nations with six mentions. That means that $20 \%$ of nations appeared only $2 \%$ of the time. Again, EC nations dominated by number mentioned ( $53 \%$ of the total),yet the landmarks actually constituted a slightly lower proportion of mentions ( $45 \%$ of the total) and most of these mentions were of Japan (highlighted in the right-hand column of Table 5). Japan is the most mentioned nation, with 102 mentions, though American mentions occurred at a similar frequency.

Table 4. Number of National Landmarks Mentioned in the Textbooks

\begin{tabular}{lccc}
\hline Measure & Inner circle & Outer circle & Expanding circle \\
\hline $\begin{array}{l}\text { Number of nations with } \\
\text { landmarks named }\end{array}$ & 4 & 3 & 8 \\
Percentage of total & 26.7 & 20 & 53.3 \\
\hline
\end{tabular}

Table 5. Frequency of Landmark Mentions

\begin{tabular}{lcccc}
\hline Measure & Inner circle & Outer circle & Expanding circle & Japan \\
\hline Number of mentions & 156 & 6 & 131 & 102 \\
Percentage of total & 53.2 & 2.0 & 44.7 & 34.8 \\
\hline
\end{tabular}

\section{Spoken Words}

Table 6 shows that EC nationals had the highest number of appearances in conversations (97). However, of these appearances, 75 were Japanese characters; Japanese nationals were the most frequently featured nationality. IC characters appeared half as much as EC characters, $26 \%$ of the time, but twice as much as EC characters when Japanese nationals are excluded.

OC characters appeared only 17 times, $9 \%$ of the total. Notably, mixed-nationality characters appeared slightly more often than OC nationals. This is primarily due to the inclusion of a major character who appeared throughout the course: Erika, a halfJapanese half-American junior high student, regularly appeared in the texts.

Table 7 shows that Japanese nationals accounted for $41 \%$ of all spoken words, the most frequent. Omitting Japanese speakers from the EC category, EC nationals accounted for 895 words ( $14 \%$ of total words spoken), placing them fourth in frequency. Second most 
frequent were IC characters (18\% of all spoken words). Third most frequent were mixednationality characters ( $15 \%$ of all spoken words). Finally, OC nationals were again least represented, accounting for only $11 \%$ of spoken discourse.

Table 6. Appearances in Conversation by Nationality

\begin{tabular}{lcccccc}
\hline Measure & $\begin{array}{c}\text { Inner } \\
\text { circle }\end{array}$ & $\begin{array}{c}\text { Outer } \\
\text { circle }\end{array}$ & $\begin{array}{c}\text { Expanding } \\
\text { circle }\end{array}$ & $\begin{array}{c}\text { Mixed } \\
\text { nationality }\end{array}$ & $\begin{array}{c}\text { Uncategorizable } \\
\text { ("foreigner"/ } \\
\text { "Arabic") }\end{array}$ & Japanese \\
\hline $\begin{array}{l}\text { Number } \\
\text { of spoken } \\
\text { character }\end{array}$ & 48 & 17 & 97 & 20 & 4 & 75 \\
$\begin{array}{l}\text { appearances } \\
\begin{array}{l}\text { Percentage } \\
\text { of all } \\
\text { appearances }\end{array}\end{array}$ & 25.8 & 9.1 & 52.1 & 10.8 & 2.2 & 40.3 \\
\hline
\end{tabular}

Table 7. Words Spoken in Conversation by Nationality

\begin{tabular}{|c|c|c|c|c|c|c|}
\hline Measure & $\begin{array}{l}\text { Inner } \\
\text { circle }\end{array}$ & $\begin{array}{l}\text { Outer } \\
\text { circle }\end{array}$ & $\begin{array}{l}\text { Expanding } \\
\text { circle }\end{array}$ & $\begin{array}{c}\text { Mixed } \\
\text { nationality }\end{array}$ & $\begin{array}{c}\text { Uncategorizable } \\
\text { ("foreigner"/ } \\
\text { "Arabic") }\end{array}$ & Japanese \\
\hline $\begin{array}{l}\text { Total number } \\
\text { of words } \\
\text { spoken }\end{array}$ & 1144 & 704 & 3513 & 932 & 54 & 2618 \\
\hline $\begin{array}{l}\text { Percentage } \\
\text { of all words } \\
\text { spoken }\end{array}$ & 18.0 & 11.1 & 55.3 & 14.7 & 0.9 & 41.2 \\
\hline
\end{tabular}

A final point is that songs reproduced in the texts were not included in the counts. However, the writers of these songs were identified as either American or British and including them would have substantially increased the proportion of IC representation in the final count.

\section{Discussion}

\section{Representation of Nations}

Japan

Japan was by far the most mentioned nation, and Japanese characters were featured and spoke the most. This demonstrates a focus on the Japanese learner of English and on Japan as the topic of language use. In fact, large sections of the textbooks were given over to information about Japan, written in Japanese, that had only a weak connection to the lesson's target language. An example of this weak connection is on page 53 of New Horizon 3 (Kasajima \& Seki, 2016f). The section describes a location in Japan. Such sections, combined with the results of this study, demonstrate a focus on the Japanese Ministry of Education mandate regarding "nurturing individual's sense of Japanese identity" (MEXT, 2014). Space available within these texts for non-language-specific information is used not to discuss other cultures, but to discuss the culture of Japan. These articles are placed in the texts with little context, disconnected from chapter goals, providing evidence that their purpose is cultural education. They are reproduced in the teacher guides without comment. A teacher could build a discussion or project around these passages, but this was clearly not an aim of the textbook designers.

\section{Inner Circle Nations}

IC nations were represented exclusively by the U.S.A., the U.K., Australia, and Canada. Overall, the U.S.A. and its landmarks were featured 123 times, and the U.K. and its

landmarks were featured 117 times. Australia and Canada were featured far less, with 36 and 28 mentions respectively. Some chapters are focused on life and travel in Australia, the U.K., and the U.S.A., for example Unit 8 of New Horizon 1 (Kasajima \& Seki, 2016d, p. 84). There were no other chapters devoted to nations in this way. Two chapter titles referenced Brazil, but these chapters were focused on a character who came from Brazil to live in Japan.

IC nations were the only countries that any characters, Japanese or otherwise, visited or resided in. Japanese characters visited only the U.K., U.S.A., or Australia or had family there. IC characters were represented in Japan or their home nations. In contrast, Deepa (from India, an OC nation) and Paulo (from Brazil, an EC nation) discussed their home nations, but they were never shown in those settings.

Additionally, in New Horizon 1 on page 37, a simulated dictionary page gives a dense description of the U.K. political makeup. The inclusion of this may indicate a belief that 
the U.K. is relevant to the English language in a way that other nations are not. No other nation had such a description of constituent parts and people.

This section is also important as the bottom right section is an entirely Japanese passage entitled "kokusaigo toshite no eigo" [English as an international language], describing this "aspect" of English: its use by people of various nationalities to communicate when they do not share a common tongue. Such a statement may be a direct response to issues identified by writers like Kubota (1998) and Toh (2012) regarding attitudes towards the ownership of English. However, in the texts, characters use English only in either a Japanese setting or an IC nation, creating a disjuncture between what is described (English as an international language) and examples in the texts.

\section{Outer Circle Nations}

OC nations were given less than $7 \%$ of the total mentions of nations and $2 \%$ of landmarks. There are two interpretations of this: (a) textbook designers did not consider or are unaware of the OC/EC dichotomy or (b) there is a negative attitude towards nonIC Englishes that is reflected in the active exclusion of OC nations.

Neither of these interpretations can be conclusively proved by this study. The inclusion of Deepa, an Indian student, as a major character suggested a conscious attempt to incorporate a non-IC speaker. However, in the texts at no point is it stated that English is Deepa's first language, nor were there discussions of English-speaking communities outside the IC. Deepa was the only OC character created for the textbooks, and it may be that the inclusion of an Indian national was due to a strengthening of India's economic relationship with Japan, rather than the status of English in India.

Furthermore, India was one of only two OC nations included in the texts to any meaningful extent (Kenya, Pakistan, and South Africa appeared only once, without discussion). The second OC nation was Ghana. The treatment of Ghana differed from the treatment of other nations, specifically other English-speaking nations.

The history of Ghana is inextricably linked with the U.K. and the English language. English is the official language of Ghana and is used as a lingua franca between diverse groups across the nation. Additionally, various forms exist: standard English and pidgin forms. Used in commerce and education, English serves as "a medium of formal and informal communication for students drawn from a variety of linguistic groups" across Ghana (Dseagu, 1996, p. 60). However, there was not a single mention of English in the Ghanaian context in any of the textbooks. Ghana was represented as a nation of poor cacao farms worked by children or by its climate and raw material exports (Kasajima \& Seki, 2016f, pp. 38-42). It is important to note that the topic of the chapter in which Ghana appeared was the Fair Trade movement, so descriptions of poverty and economy are relevant. But it must also be said that for an English-language textbook, it is a stark oversight not to mention that Ghana is an English-speaking nation. Furthermore, Ghanaian people were offered no voice; they were spoken about but not with.

\section{Expanding Circle Nations}

EC nations and nationals featured more frequently than OC nations. Excluding Japan, EC nations and landmarks were mentioned 126 times. This is less than half the total for IC nations but significant. Brazil was the most mentioned EC nation, perhaps because Brazil is home to the largest population of people of Japanese descent outside of Japan and since the 1990s, there has been a significant increase in Brazilian workers migrating to Japan (Goto, 2007). This seems especially likely as both Brazilian characters were depicted as having moved to Japan for work or study.

\section{Spoken Words}

Japan and Inner Circle Speakers

Japanese and IC speakers accounted for around $60 \%$ of all words spoken, and a further $14 \%$ were accounted for by Erika, a mixed Japanese-American national. Thus, almost three quarters of all spoken or presented language was produced by nationals of these five countries. Japanese characters were the primary users of English in these texts, which is understandable considering that the example of Japanese students speaking English seems beneficial for motivating the target audience of these textbooks.

\section{Outer Circle Speakers}

Of more concern was the treatment of OC speakers. First, the sole OC character is Deepa, an Indian national. Deepa accounts for slightly under half of all OC words. The other 398 words were found in the final pages of New Horizon 3 (Kasajima \& Seki, 2016f) and were the words of Pakistani Malala Yousafzai's speech to the United Nations in July 2013. However, the speech was altered without acknowledgment. Specifically, all allusions to Islam and almost all allusions to women's rights were removed. This famous speech (Yousafzai, 2013) included numerous references to Islam and Malala's direct statement that she was "focusing on women's rights and girls' education." This statement was itself removed. The inclusion of a speech from as admirable a figure as 
Yousafzai is to be commended, but it is worrying that these textbooks have chosen to alter without acknowledgment this cultural text in a course that is aimed at broadening the worldviews of its students.

There is a further issue in the treatment of Ghana. As discussed earlier, Ghanaian nationals were given no voice in the texts, despite Ghana being an English-speaking country. Although Ghana is a nation of multiple languages and various forms of English, there was no reference to this in any of the texts. It was their poverty that was discussed in the form of a pamphlet or a letter from a Japanese student to a Canadian (Kasajima \& Seki, 2016f). It is perhaps ironic that in this letter the Japanese student asked, "What can we do for these children?" (p. 40). A good first step, maybe, would be offering them a voice.

\section{Mixed-Nationality Speakers}

The mixed-nationality Erika may be the main character of the texts: No other character is so developed. Erika was introduced in New Horizon 1 (Kasajima \& Seki, 2016d) as a 13-year-old girl with a Japanese mother and American father. The textbook did not state her nationality, but it is safe to assume that she was a dual-nationality citizen of both the U.S.A. and Japan.

The choice to feature dual-nationality characters or partnerships appears to be a hallmark of the New Horizon courses. Yamada (2010) identified an American husband and Japanese wife in New Horizon 1 in 1997, a Japanese husband and Australian wife in New Horizon 1 in 2002, and a Japanese husband and Canadian wife in New Horizon 1 in 2006 and 2010. Yamada found this to indicate an increasingly positive attitude towards individuals of mixed ethnicity in Japan and overseas. However, these examples and the addition of an American-Japanese couple in 2016 show that the instances are exclusively of Japanese marriages with IC nationals. This observation could support Kubota's (1998) argument that Japanese textbooks situate Anglo-American English and lifestyle as the "developed, civilized, and superior" ones (p. 303). However, it also supports Yamada's opinion that the occurrences indicate a growing acceptance of mixed ethnicities, however limited. Furthermore, if in fact marriages to IC nationals are more common than others, the textbooks may reflect reality, not bias. Further research into this is necessary.

\section{Representations Over Time}

This study found that the 2016 textbooks introduced a broader range of nationalities than were seen in Yamada's earlier studies. The 2016 editions featured 18 different nationalities, 12 with substantial speaking parts. Although Japanese, American-Japanese, and American are the top three of the top seven nationalities who produce words, the next four are Pakistani, Brazilian, Canadian, and Indian origin. This is a positive improvement over the limited number of nationalities in earlier editions.

\section{Overall Findings}

Representations of English Speakers

In the 2016 edition of the New Horizon textbooks, English speakers were represented by a variety of nationalities. The majority of speakers were either Japanese or IC nationals, but over a third of the language was produced by EC nationals depicted as either living in Japan or presenting information about their home and culture to students in Japan. Thus, English speakers in these texts were either IC speakers or users of English as a foreign language.

This is a positive development. The examples of EC nationals using English for international communication facilitate learner understanding of why Japanese JHS students study a language they may not use outside the classroom. Furthermore, some scholars consider English incorporated into Japanese as a creative force in modern Japanese (see Stanlaw, 2004). If that is so, an understanding that forms of English exist outside of the IC would be beneficial for Japanese speakers.

What was missing were L1 speakers of English from beyond the IC. The single possibly OC speaker of English was Deepa, an Indian student. However, the text at no point stated that English was her primary language, though it also did not state otherwise. The inclusion of an OC character, however, creates the opportunity for teaching points within the classroom, prompting students to consider what an English speaker is. Indeed, it may be that some teachers do so. However, owing to the grammarfocused nature of the textbook guides, no such pedagogical aims were obvious.

\section{The English Language as Product}

The English language was most frequently backgrounded by the people and places of the U.S.A. The use of America as backgrounding is not itself an issue; rather, it is necessary to ask whether opportunities to represent diverse English users were overlooked.

English was also a medium for discussing Japan. Japan was the most represented nation, the setting for the textbooks, and large portions were devoted to Japan and Japanese culture. One interpretation is that this follows the MEXT goal of encouraging "self-awareness as Japanese" (Uchibori, 2014), although this could also be an attempt to 
lighten the cognitive load through the use of familiar topics. Sections featuring Japaneselanguage descriptions of Japanese locations support the former rather than latter interpretation, however.

EC nations were well represented, but OC speakers were underrepresented. English was represented as a product of IC nations, following the forms of standard American English. The use of a standard form in Japanese EFL textbooks is understandable, but students were not offered opportunities to realise they were being taught a specific form of a global language.

\section{Nationalities With Voice}

The textbooks gave voice to a variety of people. Although Japanese nationals produced the most language, a mixed Japanese-American student was most featured. Efforts were made to give voice to EC as well as IC nationals, indicating conscious efforts by the textbook creators to introduce an international element.

\section{Nationalities Without Voice}

However, OC speakers of English were underrepresented. The texts failed to address relevant issues even when the opportunity was clear: The failure to give voice to

Ghanaian nationals despite discussing the nation in depth was an unfortunate one. Furthermore, the textbook creators edited the words of Malala Yousafzai without acknowledgement. This is not merely failing to give voice to an OC national, but actually changing their words.

Essentially, as was found in previous studies, these texts framed English as the language of the IC nations, and no voice was offered to others who use English as their primary tongue. This supports Kubota's (1998) criticism that the Anglo speaker of English is represented as in some way superior, though it does not prove this conclusively.

\section{Limitations of This Study and Opportunities for Further Research}

The New Horizon series, though widespread across Japan, is one of six junior high school series. A repeat of this study on the remaining five series as well as on texts for other age groups would provide a clearer picture of overarching issues. Furthermore, this study examined solely representations of nationalities, not of other social groupings such as ethnicity or gender. Although the use of Kachru's (1985) model of world Englishes was appropriate, models such as Modiano's (1999) English as an international language model may produce different observations regarding bias in representations.

\section{Conclusion}

This study found that Japanese culture is increasingly the focus of these textbooks, to the point that they discuss Japan in Japanese, not English. After Japan, inner circle nations and nationals are most represented, although representation of expanding circle nations is significant, representing a globalized society. Excluded, however, are first-language English speakers from beyond the U.S.A, Australia, Canada, or the U.K., even when there is opportunity. Textbook creators should focus less on Japan and use texts to represent English speakers from beyond the IC nations and give voice to these speakers rather than merely using their images. Teachers should draw attention to the use of English in a global role, not merely a regional one between the West and Japan, and ask students why these characters are using English. This would help Japanese students reflect on the relevance of the language to themselves.

\section{Bio Data}

Luke Houghton holds an MA in TESOL from the University of Birmingham and an MSc in International Relations from the University of London. He is manager of the Educational Affairs Department at British Hills in Fukushima. His interests include world Englishes, task-based language teaching, and critical discourse analysis. $<$ lukehought@hotmail.com>

\section{References}

Davidson, R., \& Liu, Y. (2018). Reaching the world outside: Cultural representation and perceptions of global citizenship in Japanese elementary school English textbooks. Language, Culture and Curriculum, 33(1), 32-49. https://doi.org/10.1080/07908318.2018.1560460

Dseagu, S. A. (1996). English in Ghana. English Studies in Africa, 39(1), 57-66. https://doi.org/10.1080/00138399608691245

Goto, J. (2007). Latin Americans of Japanese origin (Nikkeijin) working in Japan: A survey. Policy Research Working Papers, 4203. https://doi.org/10.1596/1813-9450-4203

Kachru, B. B. (1985). Standards, codification and sociolinguistic realism: The English language in the outer circle. In R. Quirk \& H. Widdowson (Eds.), English in the world (pp. 11-30). Cambridge, England: Cambridge University Press. 
Kasajima, J., \& Seki, N. (Eds.). (2016a). 中学教科書ガイド 東京書籍版 NEW HORIZON 英語 1年 [New horizon textbook guide 1]. Tokyo Shoseki, Tokyo: Japan.

Kasajima, J., \& Seki, N. (Eds.). (2016b). 中学教科書ガイド 東京書籍版 NEW HORIZON 英語 2年 [New horizon textbook guide 2]. Tokyo Shoseki, Tokyo: Japan.

Kasajima, J., \& Seki, N. (Eds.). (2016c). 中学教科書ガイド東京書籍版 NEW HORIZON 英語 3年 [New horizon textbook guide 3]. Tokyo Shoseki, Tokyo: Japan.

Kasajima, J., \& Seki, N. (Eds.). (2016d). New horizon 1. Tokyo Shoseki, Tokyo: Japan.

Kasajima, J., \& Seki, N. (Eds.). (2016e). New horizon 2. Tokyo Shoseki, Tokyo: Japan.

Kasajima, J., \& Seki, N. (Eds.). (2016f). New horizon 3. Tokyo Shoseki, Tokyo: Japan.

Kirkpatrick, A. (2007). World Englishes: Implications for international communication and English language teaching. New York, NY: Cambridge University Press.

Kubota, R. (1998). Ideologies of English in Japan. World Englishes, 17, 295-306.

https://doi.org/10.1111/1467-971X.00105

Matsuda, A. (2002). Representation of users and uses of English in beginning Japanese EFL textbooks. JALT Journal, 24(2), 182-200. https://doi.org/10.37546/JALTJJ24.2-5

McConachy, T. (2018). Critically engaging with cultural representations in foreign language textbooks. Intercultural Education, 29(1), 77-88. https://doi.org/10.1080/14675986.2017.1404783

MEXT (2014). English education reform plan corresponding to globalization. Ministry of Education, Culture, Sports, Science and Technology, Japan. Retrieved from http://www.mext.go.jp/en/news/ topics/detail/__icsFiles/afieldfile/2014/01/23/1343591_1.pdf

Modiano, M. (1999). Standard English(es) and educational practices for the world's lingua franca. English Today, 15(4), 3-13.

Nippon Kyouzai Shuppan (2019). 年度教科書採択表 [Annual textbook adoption table]. Retrieved from http://www.nihonkyouzai.jp/kyozai/list/11089

Ookawa, K. (2017). Analyzing high school English textbooks in Japan and Korea. Journal of Applied Linguistics and Language Research, 4(7), 75-96. http://www.jallr.com

Phillipson, R. (1992). Linguistic imperialism. Oxford, England: Oxford University Press.

Stanlaw, J. (2004). Japanese English: Language and culture contact. Hong Kong, China: Hong Kong University Press.

Toh, G. (2012). Having English as a resource for multicultural understanding: Exploring possibilities in Japanese. ELT Journal of Multilingual and Multicultural Development, 33(3), 1-11. https://doi.org/10.1080/01434632.2012.655248

Uchibori, C. (2014). English education in Japan: An analysis of the guidelines for junior high schools. 東京女子大学言語文化研究 [Studies in Language and Culture], 23, 16-35. Retrieved from https://pdfs.semanticscholar.org/
Yamada, M. (2010). English as a multicultural language: Implications from a study of Japan's junior high schools' English language textbooks. Journal of Multilingual and Multicultural Development, 31(5), 491-506. https://doi.org/10.1080/01434632.2010.502967

Yousafzai, M. (2013, July 12). Malala Yousafzai: "Our books and our pens are the most powerful weapons.” The Guardian. Retrieved from https://www.theguardian.com/ 